\title{
Parallelism error in peanut sowing operation with auto-steer guidance
}

\author{
Adão F. dos Santos ${ }^{1}$, Rouverson P. da Silva ${ }^{1}$, Tiago O. Tavares ${ }^{1}$, \\ Antonio T. S. Ormond ${ }^{1}$, David L. Rosalen ${ }^{1} \&$ Leonardo C. de Assis ${ }^{2}$ \\ ${ }^{1}$ Universidade Estadual Paulista/Departamento de Engenharia Rural. Jaboticabal, SP. E-mail: adaofeliped@gmail.com (Corresponding author); \\ rouverson@fcav.unesp.br; tiagoolitavares@hotmail.com; tassiormond@gmail.com; rosalen@fcav.unesp.br \\ ${ }^{2}$ Universidade de Uberaba/Instituto de Ciências e Tecnologia do Ambiente. Uberaba, MG. E-mail: leonardo.assis@uniube.br
}

\section{Key words:}

autopilot

precision agriculture electric auto-steering

RTX

GNSS

\section{A B S T R A C T}

GNSS positioning errors are certain, regardless of the adopted positioning method. In agriculture, these errors may represent higher or lower overlapping rates between passes of a mechanical assembly, affecting operation quality. Therefore, this study evaluated the main errors arising from peanut sowing operation performed with an auto-steer guidance system by an RTX signal, using the Statistical Process Control techniques. The errors evaluated were: in tractor lateral displacement, project execution, and parallelism between passes of tractor-seeder set. The average errors of project execution in all passes were within the range specified by the manufacturer, i.e. lower than $3.8 \mathrm{~cm}$. The average error of tractorseeder set was also within the accepted range. However, as shown in control charts, lateral tractor displacement had interference of terrain slope, causing average errors higher than the accepted range. Based on the control charts, project execution accuracy was satisfactory, and it is possible to use the RTX signal in agricultural operations that require accuracy lower than $3.8 \mathrm{~cm}$, such as peanut sowing.

\section{Palavras-chave:}

piloto automático agricultura de precisão piloto elétrico

RTX

GNSS

\section{Erros de paralelismo provenientes da operação de semeadura de amendoim com direcionamento automático}

\section{R E S U M O}

Os erros de posicionamento pelo GNSS são inevitáveis, independentemente do tipo de posicionamento adotado. $\mathrm{Na}$ agricultura esses erros podem representar maior ou menor taxa de sobreposição entre as passadas dos conjuntos mecanizados, o que afeta, consequentemente, a qualidade da operação. Objetivou-se, neste sentido, avaliar os principais erros ocasionados durante a operação de semeadura de amendoim utilizando direcionamento automático com sinal RTX, por meio da análise do Controle Estatístico de Processo. Foram avaliados o erro de deslocamento do trator, o erro de execução do projeto, em quatro passadas, além do erro de paralelismo entre as passadas do conjunto tratorsemeadora. O erro médio de execução ficou, em todas as passadas, dentro do estipulado pelo fornecedor do sinal, com valores menores que $3,8 \mathrm{~cm}$. O erro médio do conjunto trator-semeadora encontrou-se no limite do aceitável. Já para o deslocamento lateral do trator, pela análise das cartas de controle, houve interferência da declividade na ocorrência de erros acima do estipulado. Com base na análise das cartas de controle constata-se que houve precisão para o erro de execução de projeto e que é possível utilizar o sinal RTX em operações agrícolas que requerem precisão menor que $3,8 \mathrm{~cm}$, como a semeadura de amendoim. 


\section{INTRODUCTION}

Real Time Kinematic (RTK) relative positioning via radio is the most widely used system in agriculture because it ensures errors of $2.5 \mathrm{~cm}$ (Baio \& Moratelli, 2011). However, when the distance between base and rover is greater than $10 \mathrm{~km}$, the signal starts to fail, making it necessary to install several bases or signal repeaters, raising costs (Perez- Ruiz \& Upadhyaya, 2012).

In contrast, precise point positioning method (PPP) using an RTX signal (Real Time extend) requires only a GNSS (Global Navigation Satellite Systems)receiver on the machine body and can provide accuracy higher than $2 \mathrm{~cm}$ (Monico, 2000). It makes this method an interesting alternative to mechanized farming operations. The RTX signal consists of several reference bases distributed across the globe, enabling machine position corrections in the field, with a guaranteed accuracy of $3.8 \mathrm{~cm}$ as per the signal provider.

GNSS positioning errors (systematic or random) interfere with the path planned for the machines, increasing the overlapping between passes of the mechanical assembly, regardless of the operation. Also, increased productivity and profits can be achieved by reducing parallelism errors (Ortiz et al., 2013), decreasing losses by properly aligning peanut sowing and harvesting (Jackson et al., 2011; Vellidis et al., 2014). Systematic errors can be eliminated or reduced with observation techniques (Monico, 2008), while random errors are inherent in the observations and persist even after using elimination techniques.

From the perspective of Statistical Process Control (SPC), errors in the results may be caused by common (or random) and special (or assignable) causes of variation. According to Samohyl \& Alves (2005), notable errors result from 6M factors (Manpower, Machinery, Materials, Method, Mother Nature, Measurement).

Therefore, process quality must be monitored to identify and correct these causes of error. To this end, this study evaluated the positioning errors and the quality of an autosteering system for peanut sowing operation using an RTX signal and by means of SPC analysis.

\section{Material ANd Methods}

The study was conducted in a peanut growing area with cultivar Granoleic. This area is near the geographic coordinates of $21^{\circ} 6^{\prime} 9^{\prime \prime} \mathrm{S}$ and $48^{\circ} 14^{\prime} 9^{\prime \prime} \mathrm{W}$, at a 540-m altitude. It consists of an area with a $2.5 \%$ average slope, within the WGS 84 geodetic reference system, with soil predominantly of clayey loam texture (EMBRAPA, 2013).

Peanut was sown according to a CAD designed project, which took into account the working width of the seederfertilizer set, and crop row spacing. The Autopilot guidelines were spaced $3.60 \mathrm{~m}$ apart since each pass comprised 4 sowing lines/rows spaced $0.90 \mathrm{~m}$ apart. The sowing was carried out by a PHT4 Supreme seeder-fertilizer drill mounted on a John Deere tractor, model 6110J, with $81 \mathrm{~kW}(110 \mathrm{hp})$ engine power, bias tires, and travel speed of $5 \mathrm{~km} \mathrm{~h}^{-1}$.

The tractor was equipped with an electric auto-steering system, CFX750 monitor/processor, and AG25 antenna. This model has multi-band receptors, L1 and L2, and works with
GPS, GLONASS, SBAS, RTK, OMNISTAR, and RTX. In this study the signal provided by Trimble RTX CenterPoint were used, which has a kinematic and real-time Precise Point Positioning. In the field, the electric auto-steering was calibrated before sowing, considering antenna height and seeder working width.

The errors were measured by AutoCAD 2013 software, being given by the orthogonal difference between lines, as follows in Figure 1:

a) Execution errors: based on the difference between the previously designed lines and those performed by the tractor.

b) Parallelism errors of the tractor-seeder set: given by the difference between the grooves made by the seeder's left outer line after two consecutive passes.

c) Tractor lateral displacement error: measured from the last left groove, made by the seeder, until the line performed by a tractor. This error was sampled using an R6 receptor, and then the points were overlapped on the map of the work executed by the tractor during sowing.

Errors B and C were measured at 20 sampling points along 4 rows, spaced $10 \mathrm{~m}$ apart, using an R6 receiver equipped with real-time kinematic (RTK) relative positioning ( $0.03 \mathrm{~m}$ error). While error A was given by the difference between the designed and executed maps.

Treatments were divided according to the number of machine passes. For execution and tractor lateral displacement errors, four passes (P1, P2, P3, and P4) were analysed individually; whereas, for parallelism error, the operation was evaluated as a whole (4 passes simultaneously). The tractor moving directions SW-NE and N-S were used to facilitate understanding the errors.

The variability analysis of the automatically-guided peanut seeding process was monitored using the tools of the Statistical Process Control (control charts and run charts), besides descriptive statistics with absolute values. The descriptive statistics used measures of central tendency (arithmetic mean and median) dispersion (amplitude, standard deviation, maximum, minimum, and coefficient of variation), asymmetry, kurtosis, and normality test (Anderson- Darling) at 5\% by means of Minitab software.

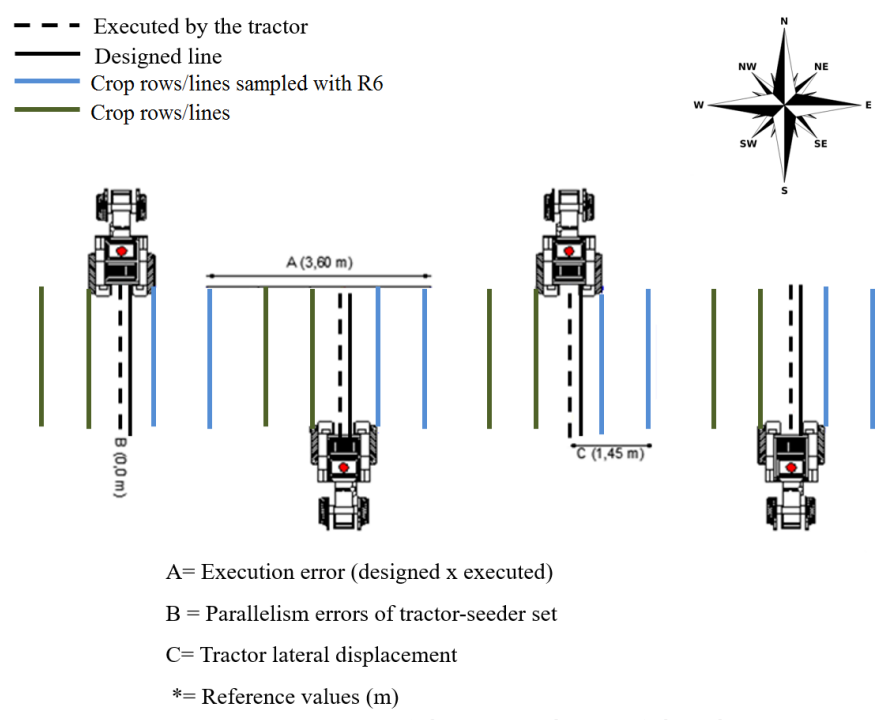

Figure 1. Representation of the sampling of the three errors evaluated, with the respective expected values (without scale) 
The selected control chart model was the Individual Moving Range (I-MR), which contains two types of charts: one that displays the individual measured values at each point - top, and one that displays the difference from one measurement to the next - bottom (Montgomery, 2009). Control limits were set considering data variation, using the averages, plus or minus twice the standard deviation, according to Santos et al. (2016). In addition to these limits, specific control limits were established referring to the average error range specified by the signal provider, which should work in $95 \%$ of the observations $( \pm 3.8 \mathrm{~cm})$.

\section{Results AND Discussion}

Table 1 shows that based on the descriptive analysis, the average errors found for the execution and tractor-seeder parallelism were within the range specified by the signal provider, i.e. lower than $0.038 \mathrm{~m}$.

The coefficients of variation were very high (Gomes \& Garcia, 2002) for both execution and tractor lateral displacement errors, in P3 and P1, respectively. The standard deviation and data range can help understand this behavior since standard deviation and range were higher for these treatments. In contrast, low $\mathrm{CV}$ values were observed for execution error in P2 and P4, which might have been due to a low amplitude and standard deviation.

Both execution and tractor lateral displacement errors, in $\mathrm{P} 3$ and $\mathrm{P} 1$, respectively, have a high data concentration to the left of the curve, which is also sharper or tapered at the top. These results indicate an asymmetrical leptokurtic data distribution (Table 2), occurring more homogeneously, concentrated on below average values, which becomes interesting when evaluating positioning errors.

The run charts (Table 2) show patterns of non-randomness, grouping, and a tendency for execution errors and grouping for parallelism errors. Unlikely, the tractor lateral displacement error showed no pattern, possibly indicating nonoccurrence of special causes in the process.
However, to verify the actual occurrence of special causes acting on the process, it is necessary to analyse the control charts. From the perspective of statistical process control, all the evaluated errors presented an unstable process, that is, under the action of special causes (Figures 2 to 4 ).

The execution error shows the occurrence of special causes in every pass of the tractor. The run charts (Table 2) showed grouping in every pass of the tractor. In general, this grouping formed two separate data groups: one at the beginning of each pass (50\% evaluated points) towards the SW-NE and NE-SW directions, and another at the end of each pass (50\% evaluated points).

This grouping results from a trending pattern of error distribution. During the first pass, the tractor was displaced to the left, resulting in negative errors (Figure 2A) to the first 10 evaluated points. Subsequently, there was a signal correction, reducing the error to close to zero, followed by a displacement to the right (positive values) in the final 10 points. Likewise, a similar behavior was observed in the other three passes (P2, P3, and P4); however, with initial error to the right and then to the left (negative values).

The errors were also smaller for displacements towards the SW-NE direction, being of 0.04 and $0.09 \mathrm{~m}$ for P1 and $\mathrm{P} 3$, respectively. Furthermore, the displacement towards the opposite direction (NE-SW) had smaller errors, 0.01 and $0.03 \mathrm{~m}$ for $\mathrm{P} 2$ and $\mathrm{P} 4$, respectively. This difference in error magnitude resulted in an increased variability for passes towards the SW-NE (P1 and P3) if compared to those towards the NE-SW direction (P2 and P4), as shown in Figure 2.

The individual-moving range charts (Figure $2 \mathrm{~B}$ ) showed smaller variability in amplitude between two points for P2 and P4 towards SW-NE. The higher values observed for P1 and P3 (NW-SE) showed higher internal variability (lower quality) of the process, that is, the error variation from one point to the other was greater for displacements towards that direction. However, the values becoming close to zero, again, is associated with the correction of systematic errors of GNSS

Table 1. Values and types of parallelism errors sampled during peanut sowing

\begin{tabular}{|c|c|c|c|c|c|c|c|c|c|}
\hline \multicolumn{10}{|c|}{ Error (m) } \\
\hline \multirow{2}{*}{ Analysis } & \multicolumn{4}{|c|}{ Execution } & \multirow{2}{*}{$\begin{array}{c}\text { Tractor-seeder } \\
\text { set }\end{array}$} & \multicolumn{4}{|c|}{ Tractor lateral displacement } \\
\hline & P1 & P2 & P3 & P4 & & P1 & P2 & P3 & P4 \\
\hline Mean error & 0.0090 & 0.0020 & 0.0288 & 0.0068 & 0.0377 & 0.0245 & 0.0762 & 0.0327 & 0.0610 \\
\hline Minimum & 0.0046 & 0.0018 & 0.0179 & 0.0059 & 0.0015 & 0.0020 & 0.0359 & 0.0101 & 0.0055 \\
\hline Maximum & 0.0134 & 0.0022 & 0.2000 & 0.0076 & 0.1191 & 0.1382 & 0.1186 & 0.0591 & 0.1065 \\
\hline CV $(\%)$ & 30.73 & 5.75 & 139.86 & 7.98 & 76.08 & 124.14 & 31.77 & 39.80 & 44.06 \\
\hline Kurtosis & -1.19 & -0.87 & 19.96 & -1.35 & 0.12 & 10.84 & -1.24 & -0.39 & -0.17 \\
\hline Asymmetry & -0.02 & -0.10 & 4.47 & -0.02 & 0.91 & 3.03 & 0.01 & -0.15 & -0.32 \\
\hline Standard deviation & 0.0028 & 0.0002 & 0.0403 & 0.0006 & 0.0287 & 0.0304 & 0.0242 & 0.0130 & 0.0269 \\
\hline Amplitude & 0.0088 & 0.0004 & 0.1821 & 0.0017 & 0.1176 & 0.1362 & 0.0827 & 0.0490 & 0.1010 \\
\hline Median & 0.0090 & 0.0020 & 0.0199 & 0.0067 & 0.0255 & 0.0151 & 0.0759 & 0.0361 & 0.0675 \\
\hline Normality (AD) & 0.2280 & 0.7170 & 0.1990 & 0.3820 & 0.9880 & $1.479^{\mathrm{AD}}$ & 0.4290 & $0.852^{\mathrm{N}}$ & 0.4380 \\
\hline
\end{tabular}

AD Non-normal by the Anderson-Darling's test, at 0.05

Table 2. Pattern occurrence analysis for the studied variables by run charts

\begin{tabular}{|c|c|c|c|c|c|c|c|c|c|}
\hline \multirow{2}{*}{ Patterns } & \multicolumn{4}{|c|}{ Execution } & \multirow{2}{*}{ Tractor-seeder set } & \multicolumn{4}{|c|}{ Tractor lateral displacement } \\
\hline & P1 & P2 & P3 & P4 & & P1 & P2 & P3 & P4 \\
\hline Grouping & $0.000 *$ & $0.000^{*}$ & $0.000 *$ & 0.000 * & $0.005^{\star}$ & 0.829 & 0.677 & 0.179 & 0.500 \\
\hline Mixed & 1.000 & 1.000 & 1.000 & 1.000 & 0.995 & 0.179 & 0.323 & 0.821 & 0.500 \\
\hline Oscillation & 1.000 & 1.000 & 1.000 & 1.000 & 0.873 & 0.711 & 0.133 & 0.711 & 0.952 \\
\hline Tendency & $0.000^{*}$ & $0.000^{*}$ & $0.000^{*}$ & $0.000^{*}$ & 0.127 & 0.289 & 0.867 & 0.289 & 0.050 \\
\hline
\end{tabular}

*Values lower than 0.05 , significant at 0.05 

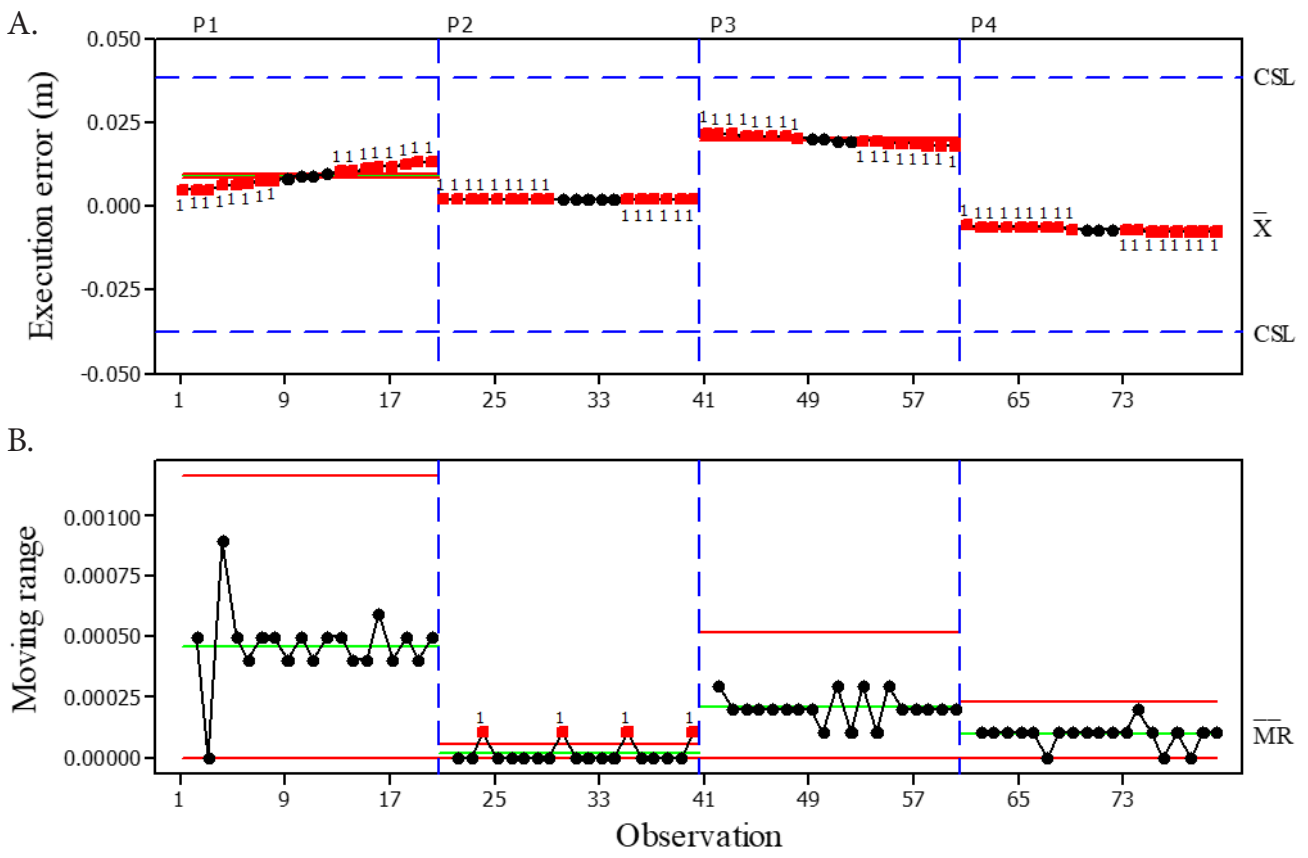

Figure 2. I-MR charts for execution error of peanut sowing process for individual (A) and moving range (B)

positioning between tractor passes returning to the path previously projected, thus increasing positioning accuracy.

The execution errors observed in this study corroborate those found by Carballido et al. (2014). These authors reported deviation values from 0.90 to $1.13 \mathrm{~cm}$ for RTX signal and concluded that it can be potentially used for positioning of agricultural tractors in precision-required operations.

Tractive forces are the main explanation the smaller errors towards the NE-SW direction (P2 and P4). These forces act according to the terrain relief, regardless of the average declivity. Moreover, the results show a proper use of machine-position compensation mechanisms since the error resulting from these acting forces was close to zero. Thus, for sowing operations in areas with a slope less than $2.5 \%$, a GNSS antenna, located on the tractor cabin, using the RTX signal, can correct systematic errors efficiently, taking into account the seeder working width.

Furthermore, an auto-steering system must have automatic compensation, so when the slope is perpendicular to the projected line, in areas with steeper slopes, this mechanism can reduce the systematic operation error. In the absence of such mechanism, the driveline is offset from the center axis of the vehicle (antenna position) (Molin et al., 2015).

Figure 3 shows the parallelism error of the tractor-seeder set. From the viewpoint of statistical process control, this process performance was unstable and inaccurate, as shown by points above and below the upper and lower control limits,
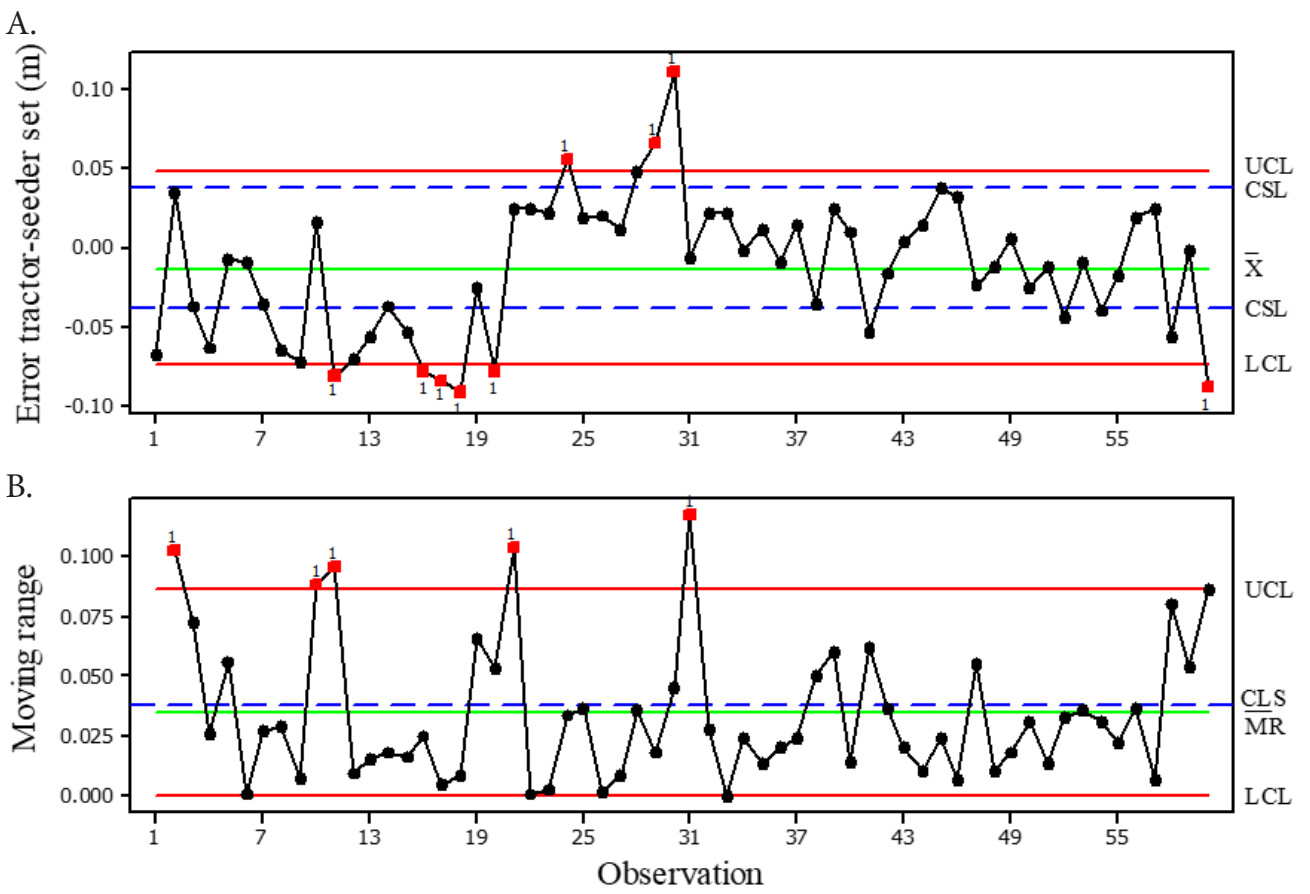

SCL: Control specific limit $(0.038 \mathrm{~m})$

Figure 3. I-MR charts for parallelism error of the tractor-seeder set in peanut sowing operation for individual (A) and moving range $(B)$ 
respectively, as well as points above and below the specific control limits, characterizing a low-accuracy process.

The results show that $65 \%$ of the points were within the specified error range. Moreover, a maximum error of about $0.12 \mathrm{~m}$ is also observed. A grouping pattern (Table 2) was also observed with the formation of two data groups, one with points from 11 to 20 and the other from 21 to 37 (Figure 3A). The process instability indicated the occurrence of special causes, which, in this case, can be attributed to the machine and environmental factors.

It is worth mentioning that when tracing a path to an automatic steering system, not necessarily the pulled equipment will follow that path, which is influenced by the coupling device. In seeders with larger working width, coupled to a traction bar, the error is higher when compared to those coupled to the third point, so it is common to use a GNSS receiver antenna on seeders with larger working width to minimize positioning errors of the pulled equipment. In this way, the working width and the coupling device of a seeder can increase or decrease-positioning errors using RTX signal.

Molin et al. (2015) stated that the main reason of the lateral slippage of a pulled equipment is the lateral thrust effect. However, these authors also pointed out that this effect tends to be less pronounced in a third-point coupling compared to a drawbar coupling since it provides a more rigid assembly.

Thus, the observed errors can be attributed to a correction provided by the auto-steering system, which seeks to maintain the path always as previously projected.

The average error shows that the RTX signal provided good results in peanut sowing, with an average of $3.8 \mathrm{~cm}$ between passes. Baio \& Moratelli (2011) and Voltarelli et al. (2013) reported parallelism errors of 3.30 and $4.88 \mathrm{~cm}$, respectively, for mechanized planting operations of sugarcane using the RTK signal.

The tractor was expected to pass $1.45 \mathrm{~m}$ away from the last furrow made by seeder. Therefore, it can be said that, as well as the execution error, the tractor positioning error was influenced by the machine moving direction and, consequently, from terrain slope (Table 2).

Allied to the slope, rolling resistance may have influenced the tractor positioning. The rolling resistance is the force expended to overcome the hysteresis between the tire and soil surface; it is given by the difference between the total tractive force and that required on the drawbar by the equipment (Neujahr \& Schlosser, 2001). These authors state that bias tires, as those used in this work, have a higher rolling loss than radial tires, which results from a smaller tire-ground contact area, thus requiring higher pressure and power to overcome the holding pressure on the soil surface, thereby increasing positioning errors.

The I-MR charts (Figure 4) show low precision and accuracy for tractor lateral displacement error in P2 and P4 with 95 and $80 \%$ of the points below specific control limits, respectively. However, despite the lack of patterns, all displacement directions were unstable, representing the occurrence of special causes (environment, machinery, and equipment). In addition, the tractor displacement might have been affected by the quality of interaction between signal and auto-steering system used. Unlike the execution error, the process internal variability (Figure 4B) was higher for passes towards the NE-SW direction (P2 and P4), which can be observed in the I-MR charts.

In addition to automatic compensation (machine factor), the quality and type of signals reaching the receiver (material factor) are extremely important to ensure lower positioning errors. The use of RTX signal with an electric auto-steering tractor to sow peanut in soil with clayey loam texture, as in this study, explain to some extent, the average errors above and below $0.038 \mathrm{~m}$.

Since the RTX signal requires no base near the area, errors increase widely due to signal degradation (environmental factor), which may arise from ionospheric refraction and, mainly, due
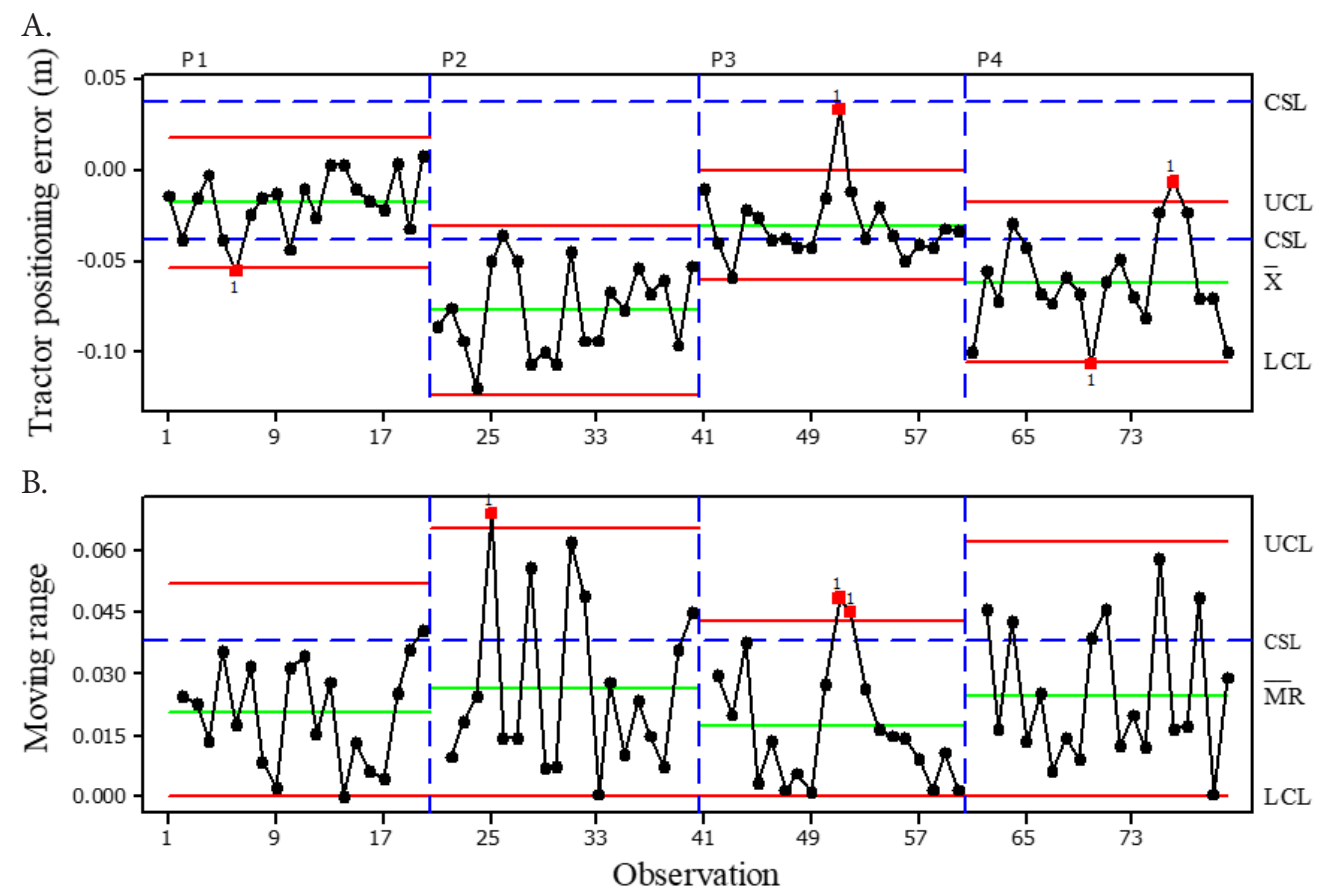

Figure 4. I-MR charts for tractor positioning error for individual (A) and moving range charts (B) 
to flickering in some periods of the day, such as in the evening. Almeida \& Dal Poz (2016) demonstrated that an ionospheric effect is the main factor interfering with the accuracy of GNSS positioning signals at a precise point. Also, the response time of an electric steering is shorter if compared to an electro-hydraulic steering, which acts directly on tractor wheelsets (Molin et al., 2015). Therefore, the interaction of these factors increases considerably tractor-positioning error. However, the results obtained here were satisfactory since Rizos et al. (2012) reported that an RTX positioning signal is able to provide a maximum real-time error of $4 \mathrm{~cm}$ in up to $95 \%$ of the observations.

\section{Conclusions}

1. The use of RTX signal for peanut sowing, with a tractorseeder set, provided average errors of execution and parallelism within the range specified by the signal provider, with precision varying from pass to pass.

2. The generated execution error (precision and accuracy) indicates the possibility of using an RTX signal for a sowing operation designed by tools CAD.

3. Positioning errors in agricultural operations using GNSS are strongly influenced by the coupling device of a tractorpulled equipment.

\section{ACKNOWLEDgment}

The Fazenda Santa Cândida by of the area and machinery for the execution of the experiment.

\section{Literature Cited}

Almeida, M. S.; Dal Poz, W. R. Precise point positioning and relative positioning with GNSS: What most accurate currently? Boletim de Ciências Geodésicas, v.22, p175-195, 2016. https://doi. org/10.1590/S1982-21702016000100010

Baio, F. H. R.; Moratelli, R. F. Auto guidance accuracy evaluation and contrast of the operational field capacity on the mechanized plantation system of sugar cane. Engenharia Agrícola, v.31, p367375, 2011. https://doi.org/10.1590/S0100-69162011000200017

Carballido, J.; Perez-Ruiz, M.; Emmi, L.; Vega, J. A. Comparison of positional accuracy between RTK and RTX GNSS based on the autonomous agricultural vehicles under field conditions. American Society of Agricultural and Biological Engineers, v.30, p.361-366, 2014.

EMBRAPA - Empresa Brasileira de Pesquisa Agropecuária. Sistema brasileiro de classificação de solos. 3.ed. Brasília: EMBRAPA, 2013. 353p.
Gomes, F. P.; Garcia, C. H. Estatística aplicada a experimentos agronômicos e florestais: Exposição com exemplos e orientações para uso de aplicativos. Piracicaba: FEALQ, 2002. 309p.

Jackson, J. L.; Beasley Jr., J. P.; Tubbs, R. S.; Lee, R. D.; Grey T. L. Fall-bedding for reduced digging losses and improved yield in strip-till peanut. Peanut Science, v.38 p.31-40, 2011. https://doi. org/10.3146/0095-3679-38.1.31

Molin, J. P.; Amaral, L. R.; Colaço, A. F. Agricultura de precisão. 1.ed. São Paulo: Oficina de Textos, 2015. 238p.

Monico, J. F. G. Point positioning of high accuracy using the GPS: A solution for geodynamics. Revista Brasileira de Geofísica, v.18, p.39-48, 2000.

Monico, J. F. G. Posicionamento pelo GNSS: Descrição, fundamentos e aplicações. 2.ed. São Paulo: UNESP, 2008. 754p. https://doi. org/10.1590/S0102-261X2000000100004

Montgomery, D. C. Introdução ao controle estatístico da qualidade. 4.ed. Rio de Janeiro: LTC, 2009. 513p.

Neujahr, E. B.; Schlosser, J. F. Performance on traction of radial and bias agricultural tires. Engenharia Agrícola, v.21, p.180-189, 2001.

Ortiz, B. V.; Balkcom, K. B.; Duzy, L.; Santen, E. van; Hartzog, D. L. Evaluation of agronomic and economic benefits of using RTK-GPS-based auto-steer guidance systems for peanut digging operations. Precision Agriculture, v.14, p.357-375, 2013. https:// doi.org/10.1007/s11119-012-9297-y

Perez-Ruiz, M.; Upadhyaya, S. K. GNSS in precision agricultural operations. In: Elbahhar, F. B.; Rivenq, A. New approach of indoor and outdoor localization systems. InTech, v.10, p.1-24. 2012. https://doi.org/10.5772/50448

Rizos, C.; Janssen, V.; Robert, C.; Grinter, T. PPP versus DGNSS. Geomatic World, v.20, p.18-20, 2012.

Samohyl, R. W.; Alves, C. C. O monitoramento de processos industriais via gráficos de controle CUSUM. Revista Univille, v.10, p.72-80, 2005.

Santos, A. F.; Silva, R. P.; Corrêa, L. N.; Borba, M. A. P.; Girio, L. A. S. Monitoramento da acurácia e precisão por meio do controle estatístico de processo. In: Congresso Brasileiro de Agricultura de Precisão - ConBAP, 2016, Goiânia. Anais... Goiânia: SBEA, 2016. CD-Rom

Vellidis, G.; Ortiz, B.; Beasley, J.; Hill, R.; Henry, H.; Brannen, H. Reducing digging losses by using automated steering to plant and invert peanuts. Agronomy, v.4, p.337-348, 2014. https://doi. org/10.3390/agronomy4030337

Voltarelli, M. A.; Silva, R. P. da; Rosalen, D. L.; Zerbato, C.; Cassia, M. T. Quality of performance of the operation of sugarcane mechanized planting in day and night shifts. Australian Journal of Crop Science, v.7, p.1396-1406, 2013. 